\title{
Khat Production and Consumption; Its Implication on Land Area Used for Crop Production and Crop Variety Production among Rural Household of Ethiopia
}

\author{
Beyene Wondafrash Ademe ${ }^{1,2, *}$, Jennifer Coates $C^{3}$, Anders Dalsgaard ${ }^{2}$, Leon Brimer ${ }^{2}$, Tefera Belachew Lema ${ }^{4}$ \\ ${ }^{1}$ Jimma University, College of Public Health and Medical Sciences, Department of Population and Family Health, Jimma, Ethiopia \\ ${ }^{2}$ Department of Veterinary and Animal Sciences, Faculty of Health and Medical Sciences, University of Copenhagen, Denmark \\ ${ }^{3}$ Tufts University School of Nutrition Science and Policy, Boston, USA \\ ${ }^{4}$ Department of Population and Family Health, College of Health Sciences, Jimma University, Ethiopia \\ *Corresponding author: beyenewondafrash@googlemail.com
}

\begin{abstract}
Khat (Catha edulis Forsk), is a stimulant plant grown mainly in Ethiopia, Yemen and Kenya. Currently it is a ubiquitous commodity cultivated and chewed; imbedded in Ethiopian culture and agriculture. In a circumstance of land degradation and scarcity farmers consider Khat as a better small-scale faming alternative; however land disposition for Khat-mono-cropping can be a disadvantage. Adjusting for the sets of alternatives on the land area to be used for crop production and on-farm crop variety is a factor that determines Khat farmers' household sustainable agriculture and livelihood. The dynamics in relation with rural households Khat production/consumption is not well explored. This study sets out to document the implication of farmers' choice of khat production and / or consumption on land use for crop production and crop variety production in rural households of Ethiopia. A panel survey using quantitative method was adopted. Data were collected in two regions of Ethiopia using pre-tested interviewer-administered questionnaire using Open Data Kit (ODK). Data were exported to STATA version SE 12(Stata Corp LP, College Station, Texas, USA). Multivariable linear regression model was run. A significantly higher proportion of khat consumers were producers $(\mathrm{P}<0.001)$. Land size used for crop production increased by 0.2 units (hectares) for khat consumers and producers as compared with No-Khat consumers and no-khat producers' households $(\beta=0.20, p<0.001)$. The likely hood of having variety of crops is two times higher for Khat consumer and Khat producer households as compared with no-Khat consumers and no-Khat producers households (AOR: 2.00 [95\%CI: 1.38, 2.91], $\mathrm{p}<0.001$ ). Land tenure system and agricultural policy and interventions should consider this Khat cropping effect among households in Khat producing areas of the country. Khat cultivation and use should be understood in a proper context in association with economical; social, cultural and environmental reality.
\end{abstract}

Keywords: Khat production and consumption, Land area used for crop production, crop variety production, ODK

Cite This Article: Beyene Wondafrash Ademe, Jennifer Coates C, Anders Dalsgaard, Leon Brimer, and Tefera Belachew Lema, "Khat Production and Consumption; Its Implication on Land Area Used for Crop Production and Crop Variety Production among Rural Household of Ethiopia.” Journal of Food Security, vol. 5, no. 4 (2017): 148-154. doi: 10.12691/jfs-5-4-5.

\section{Introduction}

Khat (Catha edulis Forsk), [1] commonly named as Khat and Abyssinian tea is a plant grown mainly in Ethiopia, Yemen and Kenya. It is chewed habitually by many people for its stimulating effect and psychosocial interaction of the consumers during the Khat session [2,3]. Its excitement effects are explained mainly by the presence of alkaloids cathinone (amphetamine like) and partly by Cathine (nor-pseudoephedrine) from fresh Khat leaves $[4,5]$. Khat chewing has been used as social custom for thousands of years in the Horn of Africa and the Arabian Peninsula [6]. In Ethiopia the history of Khat dates back to the 13th century and currently it is an abundant commodity cultivated and anomalously chewed. Researches showed that production of Khat leaf is profitable as an alternative to other crops supplementing household income and bridges the lean season in the food calendar [7,8]. In 1999/2000, for Ethiopia Khat was the second important earner of foreign exchange after coffee [9]. Another study indicated that Khat is the largest export crop, following coffee and oil seed, contributing $13.4 \%$ of the export earning to the Ethiopian economy $[10,11]$.

In Ethiopia to increase agrarian productivity through intensive farming and specialization appropriate technologies are inadequate. A study done in Ethiopian Eastern highlands portrayed that farmers struggle to increase their production through alternative on-farm activities such as replacing annual crop production by permanent Khat plantation and production, integrating perennial crops with staple food crops, crop-livestock mixed farming and cash cropping $[12,13]$. When land for food crops is substituted for Khat farming, food production could be reduced $[6,14]$. 
A case study done in one of the major Khat producer area expressed farmers' livelihoods vulnerability with Khat cultivation/consumption through household food security threat, market fluctuation, addiction and idleness spending 3 to 6 hours of session per day-by chewing Khat at homes, work places, markets, public areas and walk sides [11,15]. According to Gebissa: "Khat-based economic strategy cannot be the basis for a sound policy for a sustainable development" [16]. Another study done in southern east Ethiopia Khat growing area of Harar Zuria district verified that farmers cultivating Khat have a total cash income around three times the income of farmers who do not grow Khat, however increased income did not change the nutritional status of their children [17].

Ethiopia is a recognized global center of genetic diversity among and within several crops having ecological, conservational and livelihood advantages. Jack R. Harlan asserts: "Ethiopia provides unparalleled opportunities for studying crop plants. It is as if a vanished world had been rediscovered by use of a time machine. Here we may still learn things that history failed to record about the evolution of the agricultural system that provided the base for Western civilization" [18]. According to Nikolai Ivanovich Vavilov, a prominent Russian botanist and geneticist: "Ethiopia is primarily a land of field crops, which exist in amazing diversity of varieties [19]

In Ethiopia farmers attempt to benefit from the microclimate and soil diversity by growing different crops on their small and scattered plots. Farm households depend for their livelihoods producing food from their own farms maintaining multiple cropping and agrobiodiversity; but small and degraded land holding, unpredictable rainfall and low farm inputs affect farm productivity and management [10,20]. A research done in Harar(South east Ethiopia) on farmers coping strategies, showed the growing importance of Khat farming to the local economy and the livelihood systems of the people in the area. In the absence of possible replacements, Khat production and marketing is important to the livelihood of people in Khat production areas and the shift towards a Khat-based farm economy is becoming unavoidable [21].

Agriculture has a complex system of productivity, social attitudes, cultural practices, economic networks, environment and health factors. Ethiopia is a country of smallholder agriculture and agriculture share significance part of Ethiopia's GDP, export revenue, national food need and labor force [22]. The country`s rural households' livelihood is influenced by land holdings, land use, crop selection, crop management, soil management, rainfall pattern, weeds, pests, diseases and livestock husbandry [23]. Population growths create high competition for land and the average land holding size in Ethiopia is insufficient to feed a family [21]. According to the Central Statistical Agency (CSA-Ethiopia), In the year 2000 cropping season, $87.4 \%$ of rural households held less than two hectares and $40.6 \%$ operated on land sizes of 0.5 hectare and less [23,24].

According to article 40 of the 1995 Ethiopian constitution the land tenure system and property rights are state owned. Farmers have only usufruct rights (use rights, but with no rights to sell, mortgage or exchange of land) $[23,25]$. Some critics argue that state ownership of land prevents the development of a land market, disappoints farmers to invest on land leading to unsustainable land use practice which can compromise productivity [24].

Khat is a controversial plant. It is banned as a controlled substance by many countries such as UK, the Netherlands, China and USA but it attracts Khat farmers because it can be harvested up to 6 times per year, grow on poor soils, marginal lands and terraced hillsides and requires relatively low labor and input. It requires minimal inputs and provides secondary benefits such as animal fodder, fuel and wood for construction. Some Khat farmers consider Khat more profitable than coffee and cereals. On the contrary land disposition for Khat-mono-cropping is a disadvantage [14,26].

Farmers' decision on their land area to be used for crop production and on-farm crop variety is a factor that could regulate sustainable agriculture and household livelihood because rural livelihood is dependent on subsistence agriculture. This aspect in relation with rural households Khat production/consumption is not well explored. This study sets out to document the implication of farmers' choice of Khat production and / or consumption on land use for crop production and crop variety production in rural households of Ethiopia

\section{Methods and Materials}

\subsection{Study Setting and Population}

This study was conducted in two regions of Ethiopia (Oromia Region and the Southern Nation, Nationality and People's Region (SNNPR)) at 10 selected 'woredas (third-level administrative divisions composed of 'kebeles` (lowest administrative structures)) from Empowering New Generations to Improve Nutrition and Economic Opportunities (ENGINE) project sites.

\subsection{Sampling Procedure}

Two 'kebeles' were sampled in each 'woreda', with one kebele selected from the ENGINE program conducting nutrition-specific interventions and the other from the ENGINE program conducting nutrition-specific plus a set of nutrition-sensitive interventions. "QTR + EPI-2 (Expanded Program on Immunization)”, was used. This method of selecting households is often applied when complete enumeration and systematic or simple random sampling (SRS) are impractical [41]. In the first step, the supervisor divided the kebele into four quarters of approximately equal household den sities. In the second step, a village in the center of each quarter was selected. Third, a household in the center of each of the villages was selected. Finally, a random direction was selected from the center of the village by spinning a pen. The supervisor counted the houses along that route and chose one household using a lottery method. Subsequent households were chosen nearest to the preceding one until the sample size had been reached (1200 households). Households were allocated proportional to the size of the population of the respective administrative units (woreda and kebele). 


\subsection{Data Collection}

Data were collected during the Ethiopian lean season (rainy season months of August and September). Twenty-six data collectors and six supervisors were deployed, forming a team of two data collectors, one from a health and one from an agricultural background, and a supervisor from either of the two disciplines. Data were collected using pre-tested, interviewer-administered questionnaires with handheld HI360 Satellite programmed Samsung tablets. Open Data Kit (ODK), which works on the Android platform through Gather Data software [40], was installed on the tablets. Supervisors and enumerators were trained in using the data collection tools on Android tablets. Data were backed up at the time of collection and were regularly transferred to a server every week by wireless cellular technology.

\subsection{Measurements}

Households Khat production and consumption status were grouped in to four combinations.

i. Khat no-producer no-consumer: A household who neither produces nor consumes Khat.

ii. Khat producer consumer: A household who produces as well consumes Khat.

iii. Khat producer no-consumer: A household who produces but not consume Khat.

iv. Khat no-produce consumer: A household who does not produce but consumes Khat.

Land area used for crop production and farm crop variety production were considered as dependent variables, while Khat production and consumption categories were treated as independent variables. The study also measured different confounding variables including: non-food household expenditure, household size and non-agricultural income type. Farmers were also interviewed about their tendency for Khat consumption and crop land substitution for Khat.

Land size owned by each household was recorded from different local measurement unites such as "Timad", "Fechassa" "Kert" and "Goro" and were converted into hectares. Number of crops produced by each household was categorized as mono-cropping and more than one crop.

Households were asked about getting off-farm income and dichotomized as "Yes" for getting and "No" for not getting non-agricultural income

Various type of non-food household expenditure (utensils, medication, school fee, cloths etc.) were used to assess Non-food household expenditure. The sum score Non-food household expenditure types were categorized in to three groups.

\subsection{Data Quality}

To ensure the quality of the data collected, the questionnaire was pre-tested with $5 \%$ of the total sample that was not included in the actual study. The pre-test was conducted in two regions (Yem Special Woreda in the SNNPR and Bedele Woreda in the Oromiya Region) that had similar characteristics to those included in the main study. Modifications were made based on the pre-test assessments.
A 12-day intensive training was provided to the data collectors and supervisors. The trainees were briefed on the questions, semantics and answers, paying close attention to any issues that were not familiar to them.

During data collection, supervisors travelled with the data collection teams to ensure adherence to all protocols and to provide support and additional training and clarification. The data manager was located at Jimma University, reviewed all the data submitted from the field on a weekly basis and communicated with the study coordinator and supervisors to clarify and improve the quality of the data.

\subsection{Statistical Analyses}

Data were exported to STATA version SE 12 (Stata Corp LP, College Station, Texas, USA), cleaned and checked for missing values and outliers before analyses. First, bivariate analysis was carried out and means and proportions were compared using T-test and Chi-square tests after checking all the assumptions. Variables with significant association in the bivariate models were selected for entry into adjusted regression models. First, a multivariable linear regression model was run using Land size for crop production as a response variable. The results were presented using 95\% confidence intervals. Secondly, a multivariable logistic regression model was fitted with Crop variety as dependent variable. The results were presented as $\beta$-coefficients and 95\% Confidence intervals. All tests were two sided and p values $<0.05$ were considered as statistically significant. Descriptive analysis are tabulated to explain the tendency of Khat consumption and land disposition for Khat plantation.

\subsection{Ethical Considerations}

Ethical approval was obtained from the ethical clearance committee of Health Sciences College of Jimma University and the Tufts University (USA) institutional review board. After receiving ethical clearance, written permission was obtained from each local responsible bodies, and informed verbal consent was obtained from each study participant. Personal identifying information was not included in the questionnaire, and remained confidential.

\subsection{Operational Definitions of Terms}

Khat Consumer: A person who consumes Khat habitually (minimum of once in a week) in bundles (one bundle=up to $500 \mathrm{~g}$ edible leaf). It is not testing on occasions

Khat Producer: A person who has Khat tree-plants and/or Khat shrubs planted on farm or backyards occupying a minimum of $2 \%$ of household's land holding.

\section{Results}

Of the 1200 households included in the study, complete data were available for 1169 households (response rate of $97.4 \%)$. A significantly higher proportion of Khat consumers were producers $(\mathrm{P}<0.001)$ (Figure 1$)$. 


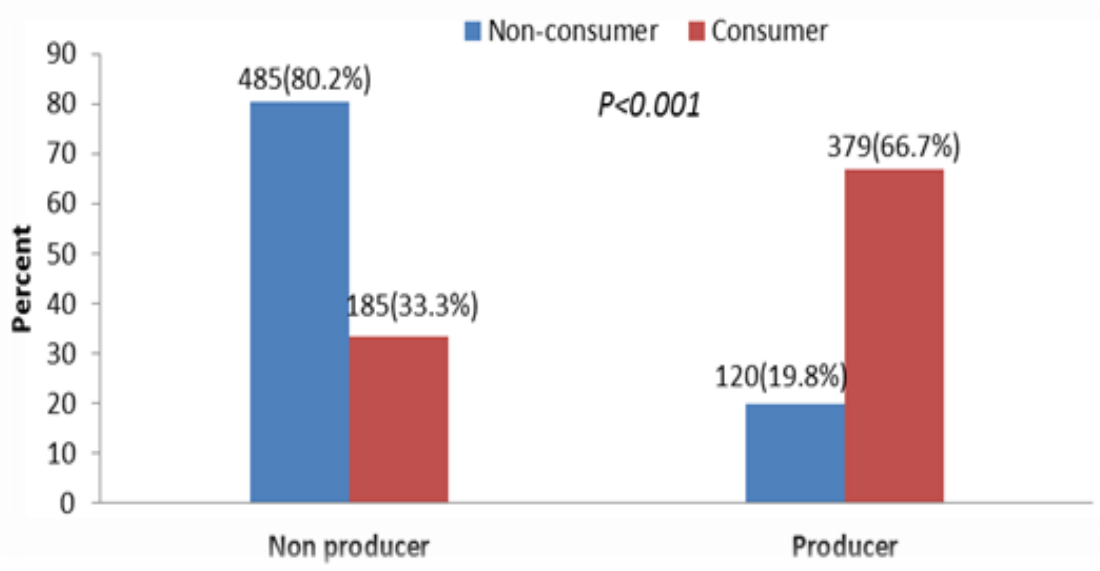

Figure 1. Association between Khat production and consumption

Descriptive statistics showed that the reason for Khat chewing varied. Most 313 (57.3\%) reported that it was for social setting or community social activities followed by 313 (56.4\%) who reported to enhance working capacity and 165 (29.7\%) referred to religious reasons. Majority $489(88.1 \%)$ of Khat chewing session were practiced in the afternoon. A total of 347 (62.5\%) chewers consume Khat daily (Table 1).

Table 1. Descriptive statistics for Khat chewing tendency of the households $(n=564)$

\begin{tabular}{llll}
\hline Reason for chewing & $\mathrm{n}(\%)$ & $\begin{array}{l}\text { Frequency of } \\
\text { Khat chewing }\end{array}$ & $\mathrm{n}(\%)$ \\
\hline To enhance working capacity & $313(56.4)$ & Daily & $347(62.5)$ \\
Belief/religion & $165(29.7)$ & Weekly & $130(23.4)$ \\
To relieve hunger & $23(4.1)$ & Monthly & $78(14.1)$ \\
Curative purpose & $145(26.1)$ & Time to chew & $\mathrm{n}(\%)$ \\
Social setting & $318(57.3)$ & Afternoon & $489(88.1)$ \\
& & Other time & $66(11.9)$ \\
\hline
\end{tabular}

Descriptive analysis showed that 340 (91.8\%) Khat chewers substituted their land holding for Khat plantation. Two hundred sixty nine (94.0\%) of Khat chewers dispose their cereal crop farm lot for Khat farming. The reason for converting land holding to Khat farming among Khat chewers varied. Two hundred eighty-eight (46.8\%) reported that it was for better income generation followed by $262(42.6 \%)$ who reported to replace infertile land (Table 2).

Table 2. Descriptive statistics for land usage and Khat consumption

\begin{tabular}{lll}
\hline Land use & \multicolumn{2}{l}{ Khat consumer } \\
\hline $\begin{array}{l}\text { Land disposition (substitution) } \\
\text { No disposition (it was Khat farm) }\end{array}$ & \multicolumn{1}{l}{ Yes (n/\%) } \\
Crop disposition & $11(9.1)$ & $30(8.1)$ \\
Cereal crops before Khat planting & $109(90.8)$ & $340(91.8)$ \\
No & & \\
Yes & $10(13.2)$ & $17(5.9)$ \\
Decision for converting land to Khat & $66(86.8)$ & $269(94.1)$ \\
For better income generation & & \\
For consumption & $99(81.8)$ & $288(46.8)$ \\
Land become infertile and need to be replaced & $11(9.1)$ & $262(42.6)$ \\
Other & $3(2.5)$ & $14(2.3)$ \\
\hline
\end{tabular}

The multivariable linear regression showed that (Table 3): being a consumer and Khat producer was positively associated with mean land size used for crop production. Land size used for crop production increased by 0.2 units (Hectare) for Khat consumers and producers as compared with non-Khat consumers and non-Khat producers' households $(\beta=0.20, \quad \mathrm{p}<0.001)$. Households produced more than two crop varieties were positively associated with mean land size used for crop production. Land size used for crop production increased by 1-unit for households producing various crops as compared with households practiced mono-cropping $(\beta=1.01, \mathrm{p}<0.001)$. Moreover a one person increased in household size increased the land size by $.09 \quad(\beta=, 0.09 \quad \mathrm{p}<0.001)$. Conversely, having nonagricultural income (off-farm income) was negatively associated with mean land size used for crop production. Average land size used for crop production decreased by 0.44 for households having more than 1 non-agricultural income type as compared with households not having non-agricultural income type $(\beta=-0.44, p<0.001)$.

Table 3. Regression model on the implication of Khat productionconsumption on land size for crop production

\begin{tabular}{lll}
\hline Land area used for crop production & Coef. (95\% CI) & P>t \\
\hline Khat production and consumption & & \\
No-Khat consumer and no-Khat producer & Reference & \\
Khat consumer and Khat producer & $0.20(0.07,0.33)$ & $<0.001$ \\
Khat consumer and no-Khat producer & $-0.01(-0.17,0.15)$ & 0.91 \\
No-Khat consumer and Khat producer & $-0.07(-0.25,0.12)$ & 0.48 \\
Non-agricultural income type & & \\
No & Reference & \\
$>1$ type & $-0.44(-0.55,0.33)$ & $<0.001$ \\
Crop variety & & \\
Mono-cropping & Reference & \\
$>=2$ crops & $1.01(0.88,1.14)$ & $<0.001$ \\
Non-food household expenditure & & $<0.001$ \\
$<3$ types & Reference & \\
3 - 5 types & $-0.11(-0.27,0.04)$ & 0.16 \\
$>5$ types & $-0.02(-0.22,0.17)$ & 0.81 \\
Household size & $0.09(0.06,0.12)$ & $<0.001$ \\
cons & $-1.40(-1.62,1.18)$ & $<0.001$ \\
\hline
\end{tabular}


As shown in Table 4 the likely hood of having a variety of crops was two times higher for Khat consumer and Khat producer households as compared with non-Khat consumers and non-Khat producers households (AOR: 2.00 [95\%CI: 1.38, 2.91], $\mathrm{p}<0.001)$. Likewise for a unit increase of land area used for crop production the likely hood of having variety of crops was four times higher (AOR: 4.20 [95\%CI: 3.09, 5.70], $\mathrm{p}<0.001$ ). Also non-food household expenditure was positively associated with having higher crop variety compared with households spending on less than 3 types of non-food items (AOR: 2.85 [95\%CI: 1.62, 5.03], $\mathrm{p}<0.001$ ). A one person increase in household size increased crop variety produce by 1.16 (AOR: 1.16 [95\% CI: 1.08,1.25], p<0.001) Conversely, Households generating more than one non-agricultural income type were $49 \%$ less likely to have higher crop variety as compared with those no non-agricultural income generators (AOR: 0.51 [95\%CI: 0.38, 0.69], $\mathrm{p}<0.001)$.

Table 4. Logistic regression on the implication of Khat productionand consumption on variety of crop production

\begin{tabular}{lll}
\hline Crop variety & AOR[95\% CI] & p-value \\
\hline Khat production and consumption & & \\
No-Khat consumer and no-Khat producer & Ref. & \\
Khat consumer and Khat producer & $2.00(1.38,2.91)$ & $<0.001$ \\
Khat consumer and no-Khat producer & $1.24(0.82,1.86)$ & 0.31 \\
No-Khat consumer and Khat producer & $1.42(0.87,2.32)$ & 0.16 \\
Land area used for crop production & $4.20(3.09,5.70)$ & $<0.001$ \\
Non-agricultural income type & & \\
No non-agricultural income & Ref. & \\
More than one non-agricultural income & $0.51(0.38,0.69)$ & $<0.001$ \\
Non-food household expenditure & & \\
Expenditure, $<3$ type & Ref. & \\
Expenditure, 3-5 type & $1.66(1.11,2.49)$ & 0.01 \\
Expenditure, >=6 type & $2.85(1.62,5.03)$ & $<0.001$ \\
Household size & $1.16(1.08,1.25)$ & $<0.001$ \\
_cons & $0.22(0.12,0.39)$ & $<0.001$ \\
\hline
\end{tabular}

\section{Discussion}

This study found that there was an association between Khat production and consumption. Significantly higher proportions of Khat consumers were Khat producers. Ethiopia is the leading Khat producer and Khat production, trade and chewing are not illegal. Khat is chewed for religious, recreational and other social reasons with a meaning of collective identity [27]. There is no Khat based trafficking and Khat production and consumption is increasing progressively. It is chewed among all categories of people irrespective of age, gender and social strata [9]; honored by some as "Leaf of Allah [6] and "flower of paradise" [28].

Khat is consumed as a social more than an isolated prescription and the distinction between use and abuse is unclear. This study detected that most consumers use it during social setting or activities (collective labor, wedding, prayers, festivals, mourning, holly days) and few consume to enhance working capacity. Chewing daily in the afternoon was the main timetable for majority of habitual users. This finding is similar with other studies done in Ethiopia in which Khat producers are users for comparable reasons. In Ethiopia an increasing use of Khat has become a concern because the habit competes for active working time and drains household economy. Expenses for Khat consumption are about \$1.5USD per day (one day's local full time labor) and duration of chewing is 3 to 8 hours per session $[11,14]$.

This study identified that Khat chewers substituted land holdings (crop farm, backyard, pastoral or other plots) for Khat plantation. Main reasons for converting land holding to Khat farming were for better income generation and because of soil infertility for food crops production. From 2001/02 to 2014/15 the land for Khat farming increased by $160 \%$ spreading out to many regions of Ethiopia $[9,29]$. According to the agricultural survey of Ethiopia 2008/2009, over 2 (3.1\%) million Ethiopian farmers cultivate Khat on their land holdings [27].

This study demonstrated that compared to households who neither produce nor consume Khat, Khat consumers` and producers` land size for crop production was higher. Similarly higher varieties of crop producers were Khat consumers and producers. The possible pulling factors for Khat producers and consumers to own more land for crop production and grow a variety of crops could be that: Khat is harvested at a regular interval (up to six harvests per annum) and that income derived from Khat could enable farmers to rent additional farm lots for seasonal cropping [14]. Besides Khat is cultivated on plots not favored for other crops and land size for crop production may not be decreased. In other areas deforestation for Khat and crop land is also additional means of farm expansion [7]. Subsistence crops or food staples are often intercropped with Khat which could increase crop divergence [15,30]. On the contrary other researches indicated that Khat farming is intensifying at the expense of food staple crops (cereals, pulses) and can reduce household food consumption with potential implications of livelihood shortage; transformation of money from cash crops to other non-household food items and men`s control on cash crops income [20,31,32,33]. Agricultural surveys showed that, cash crops such as Khat, coffee, cotton, oil crops could compete with food crops for land and labor. In Ethiopia in 2015, the land area used for Khat plantation was $44 \%$ of that used for coffee cultivation due to a volatile coffee market. In Ethiopia there is no a clear Khat policy, but criminalizing, demonizing, or prohibiting Khat cultivation could affect the livelihoods of Khat farmers, rural non-agricultural laborers and traders.

Though this study investigated the implication of Khat production and consumption on land area used for crop production and farm crop variety production alternative explanations such as non-food household expenditure, non-agricultural income type, and household size were dealt during analysis.

We observed that getting nonagricultural income (offfarm income) was negatively associated with households land size used for crop production and crop variety production. The pathways involved are farmers nonagricultural income preference was due to poor return from agriculture; small and infertile land holdings, low farming output prices and earnings; higher crop production 
input prices than its output prices; inconsistent market for the harvest; inability to feed the family and availability of off farm employment opportunities [34]. Evidences showed that, expanding income sources beyond on-farm activities such as working in agricultural and nonagricultural sectors and other off-farm location could push the farmer from on farm activities. Conversely other studies implied that non-farm income is important for food access and household economies even preventing farm degradation [35]. A Study in Ethiopia showed a positive relationship between nonagricultural income and better rural household livelihood status [36].

This study showed that farmers' household size play a significant role for the land size used for crop production and crop variety production increments. This evidence supports family size positively association with the amount of land cultivated [37] and the 'stylized facts' about developing countries, that large families tend to be poorer is debatable $[38,39]$.

Investigating the substitution effect of Khat farming in wider areas of different regions of Ethiopia might help to understand whether so many Ethiopian small holding farmers can sustain with Khat or without it. Further research is also needed to understand the role of nonagricultural income for rural household livelihood improvement and poverty alleviation harmonized with the alternative farm sectors such as Khat production

\section{Conclusion}

The results of this study demonstrated that compared to households who neither produce nor consume Khat, Khat consumers` and producers` land size for crop production and varieties of crop production were higher. Majority of Khat chewers substituted their land for Khat plantation and higher proportions of Khat consumers were Khat producers. Most consumers use Khat during social setting demonstrating its social function. Khat cultivation and use should be understood in a proper context in association with economics, social, cultural and environmental reality.

\section{References}

[1] Baack L. A naturalist of the Northern Enlightenment: Peter Forsskål after 250 years. Arch Nat Hist 2013; 40(1): 1-19.

[2] Brenneisen R, Fisch H, Koelbing U, Geisshusler S, Kalix P. Amphetamine-like effects in humans of the Khat alkaloid cathinone. Br J Clin Pharmacol 1990; 30(6): 825-828.

[3] Mela M, McBride A. Khat and Khat misuse: an overview. J Subst Use 2000; 5(3): 218-226.

[4] Gelaw Y, Haile-Amlak A. Khat chewing and its sociodemographic correlates among the staff of Jimma University. Ethiopian Journal of Health Development 2004; 18(3): 179-184.

[5] Kalix P. Cathinone, a natural amphetamine. Pharmacol Toxicol 1992; 70(2): 77-86.

[6] Gebissa E. Leaf of Allah: Khat \& agricultural transformation in Harerge, Ethiopia 1875-1991. : Ohio State University Press; 2004.

[7] Fafchamps M. Cash crop production, food price volatility, and rural market integration in the third world. Am J Agric Econ 1992; 74(1): 90-99.

[8] Cochrane L, O’Regan D. Legal harvest and illegal trade: Trends, challenges, and options in Khat production in Ethiopia. International Journal of Drug Policy 2016 4; 30: 27-34.
[9] Belwal R, Teshome H. Chat exports and the Ethiopian economy: Opportunities, dilemmas and constraints. African Journal of Business Management 2011 May 4, 2011; 5(9): 3635-3648.

[10] Aden A, Dimba EA, Ndolo UM, Chindia ML. Socio-economic effects of Khat chewing in north eastern Kenya. East Afr Med J 2006 Mar; 83(3): 69-73.

[11] Megerssa B, Esayas A, Mohamed A. Socio-Economic Impact of Khat in Mana District, Jimma Zone, South Western Ethiopia. Discourse Journal of Agriculture and Food Sciences 2014; 2(2): 21-32.

[12] Pender J, Gebremedhin B. Determinants of agricultural and land management practices and impacts on crop production and household income in the highlands of Tigray, Ethiopia. Journal of African Economies 2008; 17(3): 395-450.

[13] Benin S, Smale M, Pender J, Gebremedhin B, Ehui S. The economic determinants of cereal crop diversity on farms in the Ethiopian highlands. Agricultural Economics 2004; 31(2-3): 197-208.

[14] Kandari LS, Yadav HR, Thakur AK, Kandari T. Chat (Catha edulis): a socio economic crop in Harar Region, Eastern Ethiopia. Springerplus 2014 Oct 3; 3: 579-1801-3-579. eCollection 2014.

[15] Karlsson S. Reducing farming household vulnerability in connection to Khat cultivation 2006. 42-54.

[16] Gebissa E. Scourge of life or an economic lifeline? Public discourses on Khat (Catha edulis) in Ethiopia. Subset Use Misuse 2008; 43(6): 784-802.

[17] Seyoum E, Kidane Y, Gebru H, Sevenhuysen G. Preliminary study of income and nutritional status indicators in two Ethiopian communities. Food and Nutrition Bulletin 1986; 8(3): 37-41.

[18] Harlan JR. Ethiopia: a center of diversity. Econ Bot 1969; 23(4): 309-314.

[19] Vavilov NI. The origin, variation, immunity and breeding of cultivated plants. Soil Sci 1951; 72(6): 364.

[20] Gezon LL. Drug crops and food security: the effects of Khat on lives and livelihoods in northern madagascar. Culture, Agriculture, Food and Environment 2012; 34(2): 124-135.

[21] Mulatu E, Kassa H. Evolution of smallholder mixed farming systems in the Harar Highlands of Ethiopia: The shift towards trees and shrubs. J Sustainable Agric 2001; 18(4): 81-112.

[22] Crewett W, Bogale A, Korf B. Land Tenure in Ethiopia. Continuity and Change, Shifting Rulers, and the Quest for State Control.CAPRi Working Paper 2008; 91.

[23] Gebreselassie S. Land, Land Policy and Smallholder Agriculture in Ethiopia: Options and Scenarios. 2006. 2-10.

[24] Crewett W, Korf B. Ethiopia: Reforming land tenure. Rev Afr Polit Econ 2008; 35(116): 203-220.

[25] Haile M. New Ethiopian Constitution: Its Impact upon Unity, Human Rights and Development, The. Suffolk Transnat'l L.Rev. 1996; $20: 1$.

[26] Tefera $T$, Kirsten J, Perret S. MARKET INCENTIVES, FARMERS' RESPONSE AND A POLICY DILEMMA: A CASE STUDY OF CHAT PRODUCTION IN THE EASTERN ETHIOPIAN HIGHLANDS. Agrekon 2003; 42(3): 213-227.

[27] Dessie G. Is Khat a social ill? Ethical argument about a stimulant among the learned Ethiopians. 2013. African Studies Centre, Leiden, The Netherlands, pp. 16-28.

[28] Varisco DM. On the meaning of chewing the significance of qāt (catha edulis) in the Yemen Arab Republic. International Journal of Middle East Studies 1986; 18(01): 1-13.

[29] Cochrane L, O’Regan D. Legal harvest and illegal trade: Trends, challenges, and options in Khat production in Ethiopia. International Journal of Drug Policy 2016; 30: 27-34.

[30] Feyisa TH, Aune JB. Khat expansion in the Ethiopian highlands: Effects on the farming system in Habro district. Mountain Research and Development 2003; 23(2): 185-189.

[31] Gebissa E. Scourge of life or an economic lifeline? Public discourses on Khat (Catha edulis) in Ethiopia. Subst Use Misuse 2008; 43(6): 784-802.

[32] Govereh J, Jayne TS. Cash cropping and food crop productivity: synergies or trade-offs? Agricultural economics 2003; 28(1): 39-50.

[33] Njiru N, Muluvi A, Owuor G, Langat J. Effects of Khat Production on Rural Household's Income In Gachoka Division Mbeere South District Kenya. Journal of Economics and Sustainable Development 2013; 4(2): 54-63.

[34] Barrett CB, Reardon T, Webb P. Nonfarm income diversification and household livelihood strategies in rural Africa: concepts, dynamics, and policy implications. Food Policy 2001; 26(4): 315-331. 
[35] Reardon T, Stamoulis K, Balisacan A, Cruz M, Berdegué J, Banks B. Rural non-farm income in developing countries. The state of food and agriculture 1998; 1998: 283-356.

[36] Block S, Webb P. The dynamics of livelihood diversification in post-famine Ethiopia. Food Policy 2001; 26(4): 333-350.

[37] Boru D, Schwartz M, Kam M, Degen AA. Effects of Family Size and Wealth on Size of Land Cultivated by Borana Pastoralists in Southern Ethiopia. Hum Ecol 2015; 43(1): 15-28.

[38] Lanjouw P, Ravallion M. Poverty and household size. Econ J 1995 11; 105(433): 1415-1434.

[39] Frelat R, Lopez-Ridaura S, Giller KE, Herrero M, Douxchamps S, Djurfeldt AA, et al. Drivers of household food availability in sub-
Saharan Africa based on big data from small farms. Proc Natl Acad Sci U S A 2016; 113(2): 458.

[40] Open data kit: Tools to build information services for developing regions. Proceedings of the 4th ACM/IEEE international conference on information and communication technologies and developmentACM; 2010.

[41] Bennett S, Radalowicz A, Vella V, Tomkins A. A computer simulation of household sampling schemes for health surveys in developing countries. Int J Epidemiol 1994; 23(6): 1282-91. 